\title{
Diffuse Alveolar Hemorrhage in Systemic Lupus Erythematosus Treated with Double Filtration Plasmapheresis
}

\section{Diffüz Alveoler Hemoraji'li Sistemik Lupus Eritematozus Olgusunda Double Filtrasyon Plazmaferez}

\section{Güven ÇETIN ${ }^{1}$ id , Tuba ÖZKAN² id , Seda TURGUT², Cumali KARATOPRAK², Rumeyza KAZANCIOĞLU³ id \\ ${ }^{1}$ Department of Hematology, Bezmialem Vakif University School of Medicine, İstanbul, Turkey \\ ${ }^{2}$ Department of Internal Diseases, Bezmialem Vakif University School of Medicine, İstanbul, Turkey \\ ${ }^{3}$ Department of Nephrology, Bezmialem Vakif University School of Medicine, İstanbul, Turkey}

\section{ABSTRACT}

Diffuse alveolar hemorrhage is a rare and life-threatening complication developed in systemic lupus erythematosus (SLE). We report a case of diffuse alveolar hemorrhage in a patient with lupus nephritis. The patient presented with acute respiratory and renal failure. Therefore, she was assessed as an activation of systemic lupus erythematosus. Despite pulse methylprednisolone, immunosuppressant drugs, and intravenous immunoglobulin (IVIG) therapy, the disease progressed. The patient participated in a plasmapheresis program, and double filtration plasmapheresis (DFPP) therapy was performed for six sessions in 6 days. Soon after the initiation of DFPP, she recovered with resolution of the radiological changes within 6 days and was successfully extubated. Thus, DFPP therapy should be considered for the treatment of diffuse alveolar hemorrhage, particularly in patients of systemic lupus erythematosus with lupus nephritis.

Keywords: Diffuse alveolar hemorrhage, systemic lupus erythematosus, lupus nephritis, double filtration plasmapheresis

\section{öz}

Diffüz alveoler hemoraji, Sistemik Lupus Eritematozus (SLE) tanılı hastalarda nadir görülen ve katastrofik seyir gösteren bir klinik süreçtir. Olguda lupus nefriti tanısı ile takip edilirken diffüz alveoler hemoraji gelişen hasta anlatıldı. Ani gelişen nefes darlığı ile hastaneye başvuran hastada akut solunum yetmezliği ve böbrek yetmezliği bulguları lupus alevlenmesi olarak değerlendirildi. Pulse metilprednizolon, immunsüpresan tedavi ve intravenöz immunglobulin tedavisine rağmen iyileşme görülmedi. Double Filtrasyon Plazmaferez uygulaması ile altı seans sonunda alveoler hemoraji bulgularının klinik ve radyolojik olarak düzeldiği görüldü. Hasta altıncı gün sonunda ekstübe edildi. Olgumuz özellikle diffüz alveoler hemoraji ile birliktelik gösteren sistemik lupus eritematozus hastalarında tedavide double filtrasyon plazmaferez kullanımının akılda tutulması açısından önem taşımaktadır.

Anahtar Kelimeler: Diffüz alveoler hemoraji, SLE, lupus nefriti, double filtrasyon plazmaferez

\section{Introduction}

Diffuse alveolar hemorrhage (DAH) is a rare and life-threatening complication in patients with systemic lupus erythematosus (SLE) and systemic vasculitis $(1,2)$. Frequency in lupus vasculitis estimates in approximately $2 \%$ of patients (3). Clinical and radiological features of DAH in SLE are similar to those of other alveolar hemorrhage syndromes. In the majority of DAH associated with SLE, renal involvement is also present, and there is an increased risk for DAH in patients with known SLE (2). Clinically, patients with DAH present with dyspnea, anemia, hemoptysis, and alveolar consolidation bilaterally on chest radiography and some patients with concurrent lupus nephritis (4). Several treatment modalities have been used in the management of DAH (3). Plasmapheresis is an alternative therapy when high-dose steroids and immunosuppressive treatment fail (4).

Herein, a patient was diagnosed as an activation of SLE with DAH. We used a novel method of plasmapheresis-double filtration plasmapheresis (DFPP)-as a rescue therapy, which reduces the risks of replacement.

\section{Case Report}

A 19-year-old woman presented with shortness of breath, massive hemoptysis, and fever since 5 days. She was known to have SLE and class-IV nephritis for the last 6 years. Two years ago, she was given cyclophosphamide therapy for 6 months Cite this article as: Çetin G, Özkan T, Turgut S, Karatoprak C, Kazancıoğlu R. Diffuse Alveolar Hemorrhage in SLE Treated with DFPP. Bezmialem Science 2018; 6(3): 228-32. 
Table 1. Detailed laboratory data

\begin{tabular}{|c|c|c|c|}
\hline Test & Result & Test & Result \\
\hline WBC & $6.8 \times 103 / \mu \mathrm{L}(3.8-10)$ & AST & 34 U/L (13-35) \\
\hline Hemoglobin & $6.9 \mathrm{~g} / \mathrm{dL}(11.5-15.5)$ & ALT & 29 U/L (7-35) \\
\hline Platelets & $234 \times 103 / \mu \mathrm{L}(150-400)$ & ALP & $78 \mathrm{U} / \mathrm{L}(0-214)$ \\
\hline MCV & $76.3 \mathrm{Fl}(80-100)$ & GGT & 112 U/L (7-32) \\
\hline Hematocrit & $21.9 \%(35.5-48)$ & LDH & 436 U/L (35-104) \\
\hline Glucose & 121 mg/dL (70-100) & T. bilirubin & $0.06 \mathrm{mg} / \mathrm{dL}(0-1.2)$ \\
\hline Protein total & $4.6 \mathrm{~g} / \mathrm{dL}(6.4-8.3)$ & D. bilirubin & $0.02 \mathrm{mg} / \mathrm{dL}(0-0.3)$ \\
\hline Albumin & $2.1 \mathrm{~g} / \mathrm{dL}(3.5-5)$ & $\mathrm{Ca}$ & 6.7 mg/dL (8.6-10) \\
\hline Creatinine & $3.5 \mathrm{mg} / \mathrm{dL}(0.6-1.1)$ & $\mathrm{Na}$ & $136 \mathrm{mmol} / \mathrm{L}(136-145)$ \\
\hline Urea & $110 \mathrm{mg} / \mathrm{dL}(10-50)$ & $\mathrm{K}+$ & $6.4 \mathrm{mmol} / \mathrm{L}(3.5-5.1)$ \\
\hline Urinary protein & 2 g/day (<0.5) & INR & $1.4(0.85-1.2)$ \\
\hline C3 & 32.9 mg/dL (90-180) & CRP & $14,5 \mathrm{mg} / \mathrm{dL}(0-0.5)$ \\
\hline $\mathrm{C} 4$ & $2.95 \mathrm{mg} / \mathrm{dL}(10-40)$ & ESR & $7 \mathrm{~mm} / \mathrm{h}(<20)$ \\
\hline ANA & Positive & GFR & $15.6 \mathrm{~mL} / \mathrm{min}(71-151)$ \\
\hline c-ANCA & Negative & $\mathrm{p}-\mathrm{ANCA}$ & Negative \\
\hline Anti-GBM & Negative & Anti-dsDNA & $1 / 320$ Titer $(<1 / 100)$ \\
\hline Anti-cardiolipin IgM/lgG & Negative & $\begin{array}{c}\text { Anti-ENA } \\
\text { SsA (Ro)/SsB (La) }\end{array}$ & Negative \\
\hline $\begin{array}{l}\text { Anti-ENA } \\
\text { Scl-70/Jo-1 }\end{array}$ & Negative & $\begin{array}{c}\text { Anti-ENA } \\
\text { Sm/RNP(Sm) }\end{array}$ & Negative \\
\hline
\end{tabular}

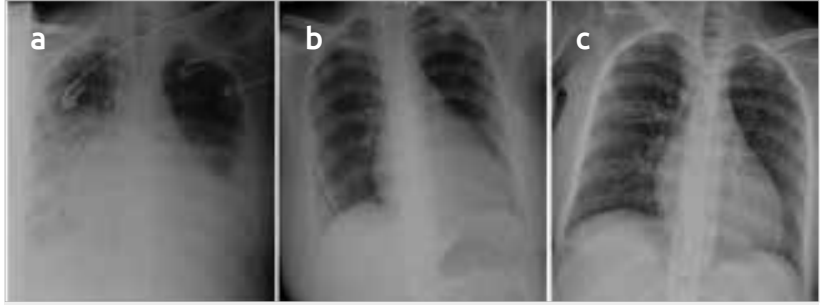

Figure 1. a-c. Chest radiographs showing the development of a left-sided pleural effusion in the patient. (a) First diagnosis (b) After six sessions of double filtration plasmapheresis (c) Last chest radiograph on $13^{\text {th }}$ day of her treatment

and had been taking prednisolone $8 \mathrm{mg} /$ day-hydroxychloroquine $200 \mathrm{mg} /$ day for 6 years.

Her blood pressure was $170 / 100 \mathrm{mmHg}$, pulse rate was 88 per min, respiratory rate was 30 per min, oxygen saturation was $75 \%$, and temperature was $36.9^{\circ} \mathrm{C}$. There were bilaterally rough respiratory sound-crackles and tachycardia on auscultation and lower extremity pitting edema. The rest of the examination was normal.

A room air arterial blood gas revealed $\mathrm{pH}$ : 7.14, $\mathrm{PO}$ : 35 $\mathrm{mmHg}, \mathrm{PCO}_{2}: 65 \mathrm{mmHg}$, and $\mathrm{SO}_{2}: 50 \%$. For close mon- itoring, the patient was intubated and placed on mechanical ventilation in the critical care unit. Laboratory results revealed microcytic anemia, hypoalbuminemia, hematuria, and proteinuria. Glomerular filtration rate was $15.6 \mathrm{~mL} / \mathrm{min}$. Urinary protein excretion for $24 \mathrm{~h}$ was $2 \mathrm{~g} /$ day. The antidouble-stranded DNA (anti-dsDNA) titer elevated at 1/320 with low complement levels (C3, C4). Anti-phospholipid, anti-glomerular basement membrane (anti-GBM) antibody, and anti-cardiolipin antibodies were negative. Detailed laboratory data are shown in Table 1 . Ejection fraction was $60 \%$, and pulmonary artery pressure was $45 \mathrm{mmHg}$ on echocardiogram. Chest radiograph showed slightly increased interstitial markings that infiltrated a left-sided pleural effusion, although diagnostic thoracentesis had revealed transudative fluid (Figure 1). Bronchoscopy and bronchoalveolar lavage were too invasive in this critically ill patient.

Depending on her clinical status, she was evaluated as an activation of SLE with DAH and treated with $750 \mathrm{mg}$ cyclophosphamide once, $2 \mathrm{~g} / \mathrm{kg} /$ day intravenous immunoglobulin (IVIG) for 2 days, $6.5 \mathrm{mg} / \mathrm{kg} /$ day hydroxychloroquine, and $500 \mathrm{mg}$ pulse intravenous methyl prednisolone for 3 days. The treatment of methylprednisolone continued at a maintenance dose of $1 \mathrm{mg} / \mathrm{kg} /$ day. 
Table 2. Double filtration plasmapheresis therapy sessions

\begin{tabular}{|c|c|c|c|c|c|c|c|c|}
\hline Sessions & $\begin{array}{c}\mathrm{Hb} \\
(\mathrm{gr} / \mathrm{dL})\end{array}$ & $\begin{array}{l}\text { Hct } \\
(\%)\end{array}$ & $\begin{array}{c}\text { Plt } \\
(/ \mu L)\end{array}$ & $\begin{array}{c}\text { Albumin } \\
\text { (gr/dL) }\end{array}$ & $\begin{array}{c}\mathrm{Cr} \\
(\mathrm{mg} / \mathrm{dL})\end{array}$ & $\begin{array}{l}\text { Time } \\
\text { (min) }\end{array}$ & $\begin{array}{c}\text { Volume } \\
\text { (Lt) }\end{array}$ & $\begin{array}{c}\text { Waste } \\
\text { (Lt) }\end{array}$ \\
\hline 11.01.2013 & 9.2 & 28.4 & 39000 & 2.1 & 3.5 & 51 & 1.8 & 0.1 \\
\hline 12.01.2013 & 9.6 & 29 & 31000 & 2.8 & 2.8 & 65 & 2.6 & 0.2 \\
\hline 13.01.2013 & 9.3 & 28.6 & 29000 & 2.9 & 0.8 & 68 & 2.6 & 0.1 \\
\hline 15.01 .2013 & 9.9 & 28.9 & 27000 & 3 & 0.8 & 76 & 3 & 0.2 \\
\hline 17.01 .2013 & 7.6 & 22.1 & 80000 & 2.9 & 2.1 & 76 & 3 & 0.1 \\
\hline 23.01.2013 & 8.6 & 25.9 & 80000 & 2.8 & 2.6 & 63 & 2.5 & 0.1 \\
\hline
\end{tabular}

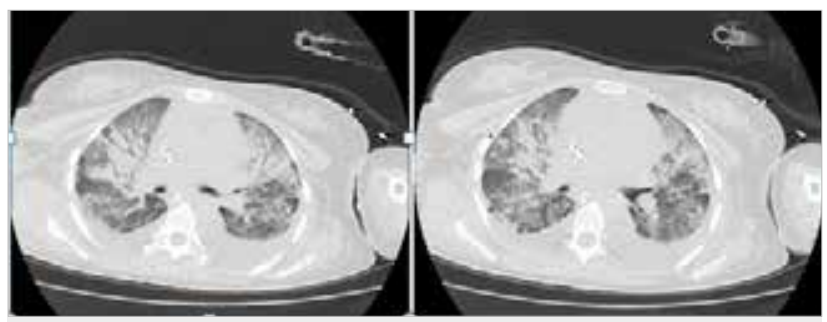

Figure 2. CT thorax with contrast showing diffuse alveolar opacities in central (perihilar) distribution

Additionally, eight packed red blood cell transfusions were given because of DAH, and four packed platelet apheresis were transfused due to immunosuppressive therapy. When her urine output was $<500 \mathrm{cc} / 24 \mathrm{~h}$ with hypervolemia, she was treated with hemodialysis therapy for six sessions. Despite medical treatment, her condition continued to deteriorate, and $72 \mathrm{~h}$ after the initiation of treatment, she had a temperature of $38.8^{\circ} \mathrm{C}$ along. During the medical treatment, hemoptysis severity increased and frequency with oxygen desaturation progressively worsened. Contrast computed tomography of the thorax revealed diffuse alveolar opacities in central (perihilar) distribution (Figure 2). She then received DFPP accompanied with hemodialysis, intravenous $40 \mathrm{mg} /$ day methylprednisolone, and oral $6.5 \mathrm{mg} / \mathrm{kg} /$ day hydroxychloroquine therapy.

Blood was drained from the body via the median cubital vein and separated into blood cell and plasma components using a Plasmaflo OP-05W (Asahi Kasei Medical Co., Ltd., Chiyodaku, Tokyo, Japan) membrane-type plasma separator. Pathogenic substances were removed from the isolated plasma using a Cascadeflo EC-50W (Asahi Kasei Medical Co., Ltd.) plasma component separator, and plasma and blood cells were returned to the subject. An ACH $\Sigma$ (Asahi Kasei Medical Co., Ltd.) blood purification device equipped with an extracorporeal circulation pump was used for blood and plasma circulation. Conditions were set as follows: blood flow rate, $30-60 \mathrm{~mL} / \mathrm{min}$; plasma separation speed, $30 \%-33 \%$ of the blood flow speed (plasma flow rate: $10-18 \mathrm{~mL} / \mathrm{min}$ ); and liquid waste flow rate, $1.5-3.0 \mathrm{~mL} / \mathrm{min}$ (5). Heparin was used as the anticoagulant.
Immediately after the initiation of DFPP, she improved with resolution of the radiological changes in the sixth session (Figure 1). She did not require hemodialysis and was extubated and discharged from clinic. Data on DFPP sessions are shown in Table 2. On the $20^{\text {th }}$ day of admission to the hospital, laboratory data revealed that anti-dsDNA titer was negative $(<1 / 100)$ with ANA positivity. Her last chest radiograph is shown in Figure 1. Patient's father signed consent form that allows releasing her medical information.

\section{Discussion}

DAH is usually presented with the "classic triad" of hemoptysis, rapid fall in hemoglobin over 24-48 h, and new alveolar or interstitial infiltrates described in the literature $(1,2,6)$. It is a rare complication in SLE. Very few studies have been published, and pathogenic mechanisms of DAH in SLE are not completely understood. The most frequent cause of admission to the hospital is pulmonary capillaritis in patient with SLE (2). Pulmonary capillaritis is vasculitis of microcirculation of the lung (alveolar capillaries, arterioles, and venules). This provides the distinction between pulmonary vasculitis that is inflammation of the lung vessels of any size $(2,6)$.

Capillaritis begins with the neutrophilic infiltration of interstitial area, followed by the disruption of the alveolar-capillary basement membranes, finally resulting in fibrinoid necrosis of capillary-alveolar wall. This causes the accumulation of red blood cell, fibrin, and fragmented neutrophil in alveolar spaces (2). These histopathological findings are detected by bronchoscopy or transbronchial lung biopsy (TBB) for convenient patients (3). The most common extrapulmonary manifestation is renal involvement, usually class III or IV nephritis. Serologically high titers of anti-dsDNA, hypocomplementemia, and anemia are frequently noted (7). The most common causes of death are respiratory failure due to massive bleeding and concomitant nosocomial infection (3).

In our case, clinical, laboratory, and radiological findings were concordant with DAH as a presentation of SLE. Even if bronchoscopy or TBB was not performed, the patient was assessed as a capillaritis syndrome who was admitted with massive hemoptysis. Mechanical ventilation was required suggesting a rather critical condition. 
The mainstay of therapy is corticosteroid drugs for DAH, particularly if associated with systemic and pulmonary vasculitis, but additional immunosuppressive agents, IVIG, and supportive ventilation are often required $(1,6)$. However, drug regimens have several differences between specific clinicians (1). For patients with incomplete remission or treatment resistance, plasmapheresis is a beneficial technique (4). Although there are no enough long-term series regarding the effectiveness on survival, few cases have shown that plasmapheresis can be used as a rescue therapy for some vasculitisrelated pulmonary bleeding (3).

Plasma exchange (PE) is a common type of plasmapheresis, but it has potential risks of viral contamination, anaphylactic reactions, and citrate-induced hypocalcemia due to the frequent use of fresh-frozen plasma (FFP) (8). In a study by Santos-Ocampo et al. (1), depending on the theoretical risk of increased autoantibody synthesis, minimized cytotoxic agent was used before initiating plasmapheresis.

The patient was given an induction therapy with corticosteroids and cyclophosphamide for DAH with lupus nephritis. Additionally, she received hemodialysis therapy in consequence of acute renal failure due to underlying lupus nephritis. Although it was refractory to treatment with cyclophosphamide, pulse corticosteroids, and IVIG, we tried another technique of plasmapheresis-DFPP-which separates plasma from blood through a plasma filter and removal of components of plasma fractionator (5).

Double filtration plasmapheresis is slightly different from $\mathrm{PE}$ and other effective treatments in various autoimmunemediated diseases $(9,10)$. In a study on therapeutic apheresis in neuroimmunological disorders, patient outcomes were compared between DFPP and PE therapies, which revealed that both DFPP and PE are effective therapies. However, the short-term effectiveness of PE was better than that of DFPP, and there was no difference between PE and DFPP in the long term (10). There are not enough data on differences between the effects of PE and DFPP on DAH syndromes, but in a reported case with DAH, DFPP was successfully accomplished without FPP, thus eliminating chances of transfusion-transmitted infections and anaphylactic shock (9).

Double filtration plasmapheresis was preferred for this young patient over PE to reduce the risks of viral contamination, allergic reactions, citrate-induced hypocalcemia, and particularly volume overload. Therefore, she was not exposed to FPP complications, and on the sixth session of DFPP, clinical remission was successfully accomplished. When we observed the effects of DFPP on extrapulmonary manifestations, we considered that it could be associated with reduced circulating immune complex levels. Few studies have expressed the impact of plasmapheresis in renal recovery, but the authors have not mentioned DFPP in these studies (9).

\section{Conclusion}

Therefore, we suggest that DFPP should be considered as a treatment for SLE-associated DAH in the context of active disease where conventional treatment has failed to induce a rapid response. Because DAH is life-threatening, the threshold for initiating DFPP should be low and long-term studies should be performed to examine the advantages/disadvantages of this method.

Informed Consent: Written informed consent was obtained from patients' parents who participated in this study.

Peer-review: Externally peer-reviewed.

Author Contributions: Concept - G.Ç.; Design - G.Ç.; Supervision - R.K.; Resources - C.K.; Materials - S.T.; Data Collection and/ or Processing - T.Ö.; Analysis and/or Interpretation - G.Ç.; Literature Search - S.T.; Writing Manuscript - T.Ö.; Critical Review R.K.; Other - C.K.

Conflict of Interest: The authors have no conflicts of interest to declare.

Financial Disclosure: The authors declared that this study has received no financial support.

Hasta Onamı: Yazılı hasta onamı bu çalışmaya katılan hastanın ailesinden alınmıştır.

Hakem Değerlendirmesi: Dış bağımsız.

Yazar Katkıları: Fikir - G.Ç.; Tasarım - G.Ç.; Denetleme - R.K.; Kaynaklar - C.K.; Malzemeler - S.T.; Veri Toplanması ve/veya İşlemesi - T.Ö.; Analiz ve/veya Yorum - G.Ç.; Literatür Taraması - S.T.; Yazıyı Yazan - T.Ö.; Eleştirel İnceleme - R.K.; Diğer - C.K.

Çıkar Çatışması: Yazarlar çıkar çatışması bildirmemişlerdir.

Finansal Destek: Yazarlar bu çalışma için finansal destek almadıklarını beyan etmişlerdir.

\section{References}

1. Santos-Ocampo AS, Mandell BF, Fessler BJ. Alveolar hemorrhage in systemic lupus erythematosus: presentation and management. Chest 2000; 118: 1083-90. [CrossRef]

2. Lara AR, Schwarz MI. Diffuse alveolar hemorrhage. Chest 2010; 137: 1164-71. [CrossRef]

3. Shen M, Zeng X, Tian X, Zhang F, Zeng X, Zhang X, et al. Diffuse alveolar hemorrhage in systemic lupus erythematosus: a retrospective study in China. Lupus 2010; 19: 1326-30. [CrossRef]

4. Claridge S, Das P, Dorling A, Robson MG. Plasmapheresis as rescue therapy for systemic lupus erthyematosus-associated diffuse alveolar haemorrhage. BMJ Case Rep 2011: p. bcr0220113893. [CrossRef]

5. Lumlertgul D, Suteeka Y, Tumpong S, Bunnachak D, Boonkaew S. Double filtration plasmapheresis in different diseases in Thailand. Ther Apher Dial 2013; 17: 99-116. [CrossRef] 
6. Park MS. Diffuse alveolar hemorrhage. Tuberc Respir Dis (Seoul) 2013; 74: 151-62. [CrossRef]

7. Virdi RP, Bashir A, Shahzad G, Iqbal J, Mejia JO. Diffuse alveolar hemorrhage: a rare life-threatening condition in systemic lupus erythematosus. Case Rep Pulmonol 2012: 836017. [CrossRef]

8. Shemin D, Briggs D, Greenan M. Complications of therapeutic plasma exchange: a prospective study of 1,727 procedures. J Clin Apher 2007; 22: 270-6. [CrossRef]
9. Iwatani H, Uzu T, Kakihara M, Nakayama Y, Kanasaki K, Yamato M, et al., A case of Wegener's granulomatosis with pulmonary bleeding successfully treated with double filtration plasmapheresis (DFPP). Clin Exp Nephrol 2004; 8: 369-74. [CrossRef]

10. Lyu RK, Chen WH, Hsieh ST. Plasma exchange versus double filtration plasmapheresis in the treatment of Guillain-Barré syndrome. Ther Apher 2002; 6: 163-6. [CrossRef] 